www.jmscr.igmpublication.org

Impact Factor 5.244

Index Copernicus Value: 83.27

ISSN (e)-2347-176x ISSN (p) 2455-0450

crossref DOI: _http://dx.doi.org/10.18535/jmscr/v4i8.97

Journal Of Medical Science And Clinical Research

\title{
Pre-Operative Shaving Versus Trimming and Their Relation to Post Operative Surgical Site Infection (SSI), A Randomized Controlled Trial
}

\author{
Authors \\ Dipak M Varia ${ }^{1}$, Samir Kacheriwala ${ }^{2}$ \\ M.S. (General Surgeon), Department of Surgery, Government medical college Baroda, Vadodara, India \\ Corresponding Author
}

Dipak M. Varia

Address: 14, Tapi Darshan Soc.-2, Near Cause Way Circle, Singan Por, Surat-4

Email:drdip1307@gmail.com, Contactno.:8511175728

\begin{abstract}
Background: Before conducting any surgery pre-operative hair removal is needed. Different methods that are currently in usage are: shaving with razor, electric trimming, and depilatory cream. This study aimed to evaluate the relationship of two methods of preoperative hair removal trimming and shaving to postoperative SSI.

Aim and Objectives: To determine the impact of two techniques: pre-operative shaving versus trimming of hair, on the incidence of post-operative SSI.

Methods: Data was collected from the department of surgery at SSGH in the period from December 2014 to January 2016. The patients were randomized into two groups. Wounds were inspected on $3^{\text {rd }}, 5^{\text {th }}, 30^{\text {th }}$ post-op day for SSI, and classified in categories according to SSI classification given by Centre for Disease Control and Prevention's (CDC)

Results: Total 365 patients were studied. Trimming group: 184, Shaving group: 181. Total 26 patients reported SSI, out of which 17 patients with razor shaving developed SSI, while 9 patients with trimming developed SSI. Method of hair removal and SSI was statistically insignificant ( $p=0.14)$. Out of 270 patients who underwent hair removal a day before surgery; 24 patients developed SSI (8.88\%) and 95 patients who underwent hair removal just before surgery; 2 patients developed SSI $(2.10 \%)$. Significant association was found between hair removal day before surgery and SSI $(p=0.04)$.

Conclusion: Pre-operative hair removal with razor shaving increases the rate of SSI as compared to trimming and SSI increases further more if hair removal done day before surgery.

Keywords: Shaving, trimming, postoperative SSI.
\end{abstract}

\section{INTRODUCTION}

There are several factors that can increase a patient's risk for a surgical site infection. The Centers for Disease Control and Prevention's (CDC) Healthcare Infection Control Practices Advisory Committee (HICPAC) has identified preoperative hair removal, antibiotic prophylaxis, glycemic control, and normo-thermia, as important modifiable risk factors for SSIs. ${ }^{[1]}$

Surgical site infections (SSIs) are a significant source of patient's morbidity and mortality, extended hospital stays, and increased health care costs. 
Hair has often been perceived to be associated with a lack of cleanliness and its removal is related to infection prevention. For these reasons, patients undergoing surgery routinely had hair removed from the site of the incision, as this was thought to reduce the chance of the surgical site becoming infected. ${ }^{[2]}$

Shaving with a disposable safety razor had been the most common and is the cheapest method of hair removal. This method uses a sharp blade, held within the head of a razor, which is drawn over the patient's skin to cut the hair close to the surface of the skin. It can result in microscopic cuts and abrasions, which then provide an area where bacterial flora can enter and multiply and potentially infect the surgical incision site. ${ }^{[2]}$

The use of depilatory cream removes the hair from the surgical site through a chemical, rather than a mechanical action. Depilatory creams are easy to apply and prevent the mechanical trauma to the skin associated with shaving. However, they are costly, and generate a sensitivity reaction at the surgical site. ${ }^{[2]}$

The use of powered surgical clippers is an alternative to shaving with a razor for hair removal. Surgical clippers use fine teeth to mechanically trim the hair close to the patient's skin, leaving short stubble of usually about one millimeter in length. Surgical clippers effectively remove hair from the operative site and also avoid the skin trauma caused by the sharp blade of a razor, since they do not come into contact with the patient's skin. ${ }^{[2]}$

\section{PATIENTS AND METHODS}

Randomized controlled trial was conducted and data was collected from the department of surgery at SSGH in the period from December 2014 to January 2016. All patients who had undergone clean and clean-contaminated surgery, and between age group of 20 - 60 year were included. Patient with immunosuppressive disease, like HIV, Diabetes, carcinoma, patient on steroids, antibiotics pre-operatively, and patient with self hair removal were not included. Routine investigations of all patients were within normal limits. No co-morbid condition was present in any of the patient included in this study. The different factors affecting post-operative infection like preexisting illness, nutritional status, pre-operative hospital stay of patient were kept more or less constant in all patients.

Patients were given serial number as per their date and time of admission. The patients were randomized into two groups $\mathrm{A}$ and $\mathrm{B}$, by random number given by the computer, and they were allocated by staff nurse, who was not be further involved in evaluation of the patients for study. The patients who were in group A had undergone trimming and those were in group B had undergone razor shaving.

Those patients who had came for day care surgery and emergency operative procedure had hair removal just prior to operative procedure; while those patients who had undergone planned surgery, had hair removal day before surgery between 1 to 3 p.m. by different operators. Operative field was examined by a resident doctor for adequacy of hair removal. The same resident doctor was debarred from conducting the postoperative evaluation.

Post-operatively, wounds were inspected on third, fifth and seventh days then after one month, in case of any discharge from wound, it was sent for culture and sensitivity. Wounds were classified in to three categories according to surgical site infection classification given by Centre for Disease Control and Prevention's (CDC) and the National Healthcare Safety Network. ${ }^{[1]}$

Grade I: Superficial incisional SSI

Grade II: Deep incisional SSI

Grade III: Organ-space SSI

\section{STATISTICAL METHODS}

Statistical analysis was done by SPSS software. Chi-square $\left(\mathrm{X}^{2}\right)$ test was used for analysis of categorical data. The $\mathrm{p}$-value for significance level was set at 0.05 . 


\section{RESULTS}

A Randomized controlled trial on 365 patients of "PRE-OPERATIVE SHAVING VERSUS TRIMMING AND THEIR RELATIONSHIP TO THE SURGICAL SITE INFECTION, A RANDOMIZED CONTROLLED TRIAL" was conducted. Patients were randomized in two groups:

In trimming group (group A) total patients: 184 .

In razor shaving group (group B) total patients: 181.

Table1: Distribution of patients according to age.

\begin{tabular}{|l|l|l|l|}
\hline Age (in year) & Group A & Group B & Total \\
\hline 20-40 year & 108 & 119 & 227 \\
\hline 40-60 year & 76 & 62 & 138 \\
\hline
\end{tabular}

All the patients were comparable in both the

9 patients with hair removed by trimmer group. Total 26 numbers of the patients reported with superficial SSI. Out of which 17 patients developed SSI. All the patients had developed (grade I) Superficial incisional SSI. with hair removed by razor developed SSI, while

Table 1: Distribution of patients with SSI in both group.

\begin{tabular}{|l|l|l|l|l|}
\hline Group & SSI & No SSI & Total & Analysis \\
\hline Group A & 9 & 175 & 184 & \\
\hline Group B & 17 & 164 & 181 & $\mathrm{X}^{2}=2.15$ \\
\hline Total & 26 & 339 & 365 & $\mathrm{P}=0.14$ \\
\hline
\end{tabular}

There was no significant association found between the two groups, trimming and shaving in respect to SSI ( $p$ value $>0.05$ ).

\section{Distribution of patients with SSI in both group}

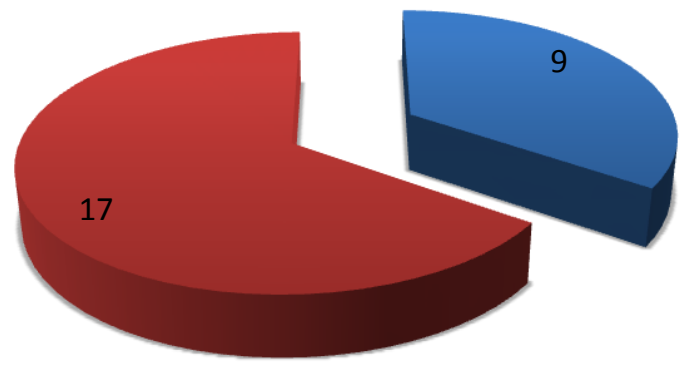

Group A

- Group B

Figure 1: Distribution of patients with SSI in both group.

Patients who underwent clean-contaminated type SSI, while this rate was less in patients who of surgery with razor shaving developed more underwent trimming with clean surgery.

Table 2: Distribution of patients with type of surgery and SSI

\begin{tabular}{|l|l|l|l|l|l|l|l|}
\hline \multirow{2}{*}{ Type of Surgery } & \multicolumn{4}{|l|}{ Group A } & \multicolumn{2}{l|}{ Group B } & \multirow{2}{*}{ Total } \\
\cline { 2 - 7 } & Total & SSI & \% & Total & SSI & \% & \\
\hline Clean & 115 & 4 & 3.47 & 102 & 6 & 5.88 & $10 / 217(4.60 \%)$ \\
\hline Clean-contaminated & 69 & 5 & 7.24 & 79 & 11 & 13.92 & $16 / 148(10.81 \%)$ \\
\hline Total & 184 & 9 & & 181 & 17 & & $26 / 365$ \\
\hline
\end{tabular}

Timing of hair removal before the surgery in respect to SSI was found to be statistically significant ( $\mathrm{p}$ value $<0.05)$. 
Table 3A: SSI according to timing of hair removal

\begin{tabular}{|l|l|l|l|l|l|l|l|}
\hline \multirow{2}{*}{ Timing } & \multicolumn{3}{|l|}{ Group A } & \multicolumn{3}{l|}{ Group B } & \multirow{2}{*}{ Total } \\
\cline { 2 - 8 } & Total & SSI & $\%$ & Total & SSI & $\%$ & \\
\hline $\begin{array}{l}\text { Just before } \\
\text { Surgery }\end{array}$ & 54 & 1 & 1.85 & 41 & 1 & 2.43 & $2 / 95(2.10 \%)$ \\
\hline Day before Surgery & 130 & 8 & 6.15 & 140 & 16 & $11.42 \%$ & $24 / 275(8.88 \%)$ \\
\hline Total & 184 & 9 & & 181 & 17 & & 26 \\
\hline
\end{tabular}

Table 3 B: Statistical analysis;

\begin{tabular}{|l|l|l|l|l|}
\hline Timing & SSI & No SSI & Total & Analysis \\
\hline Just before Surgery & 2 & 93 & 95 & \\
\hline Day before Surgery & 24 & 246 & 270 & $\mathrm{X}^{2}=3.91$ \\
\hline Total & 26 & 339 & 365 & $\mathrm{P}=0.04$ \\
\hline
\end{tabular}

The most common organism isolated was Klebsiella 7/21 (33.33\%) and E.coli 7/21 $(33.33 \%)$. In shaving group it was staphylococcus and in trimming group it was Klebsiella which was more common.

Table 4: SSI According to the type of organism

\begin{tabular}{|c|c|c|c|c|c|c|}
\hline \multirow[b]{2}{*}{ Groups } & \multicolumn{6}{|l|}{ Organism } \\
\hline & $\begin{array}{l}: \overline{0} \\
0 \\
\\
\end{array}$ & 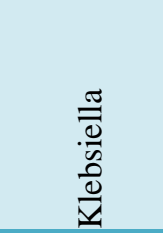 & 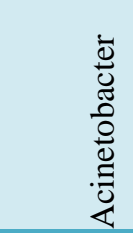 & 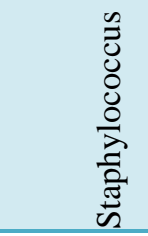 & 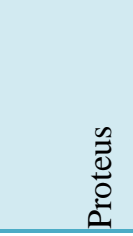 & 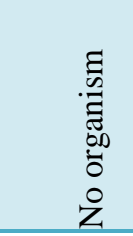 \\
\hline Group A & 1 & 3 & 0 & 2 & 1 & 2 \\
\hline Group B & 3 & 4 & 1 & 5 & 1 & 3 \\
\hline Total & $\begin{array}{l}4 \\
(19.04 \%)\end{array}$ & $\begin{array}{l}7 \\
(33.33 \%)\end{array}$ & $\begin{array}{l}1 \\
(4.76 \%)\end{array}$ & $\begin{array}{l}7 \\
(33.33 \%)\end{array}$ & $\begin{array}{l}2 \\
(9.52 \%)\end{array}$ & $\begin{array}{l}5 \\
23.80 \%)\end{array}$ \\
\hline
\end{tabular}

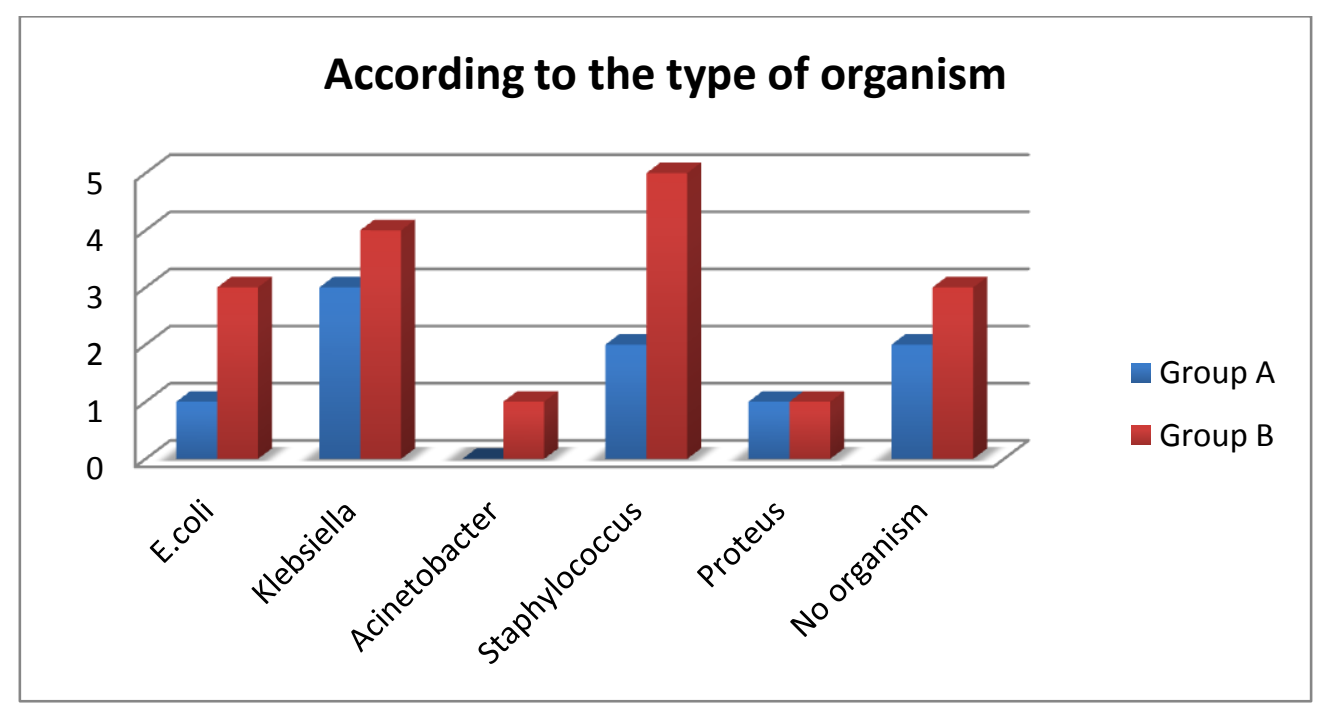

Figure 1: SSI According to the type of organism

\section{DISCUSSION}

Preparing a patient for surgery frequently involves removing hair around the surgical site. Studies have shown a direct link between surgical site infections and hair removal, although questions remain about the best method to use. Appropriate removal of hair does help prevent surgical site infections. Shaving has traditionally been the most 
common method used to prepare the skin before surgery. But the best method of removing hair is debatable. Razors can rapidly remove hair from the surgical field, but may result in small cuts and abrasions. This minor skin damage can provide an area where bacteria flora can multiply and potentially infect the surgical incision site.

An alternative to using razors is powered surgical clippers. Clippers mechanically trim hairs close to the skin, effectively removing it from the field, and avoid skin trauma caused by the sharp blade of a razor. Reviews of other randomized controlled trials have supported this. ${ }^{[2]}$

In present study, 9.39\% patients with trimming developed superficial SSI as compared to $4.89 \%$ patient with shaving. Rate of SSI following shaving was higher as compared to trimming but it was not statistically significant.

Several studies mentioned below also suggest that trimming reduces the rate of surgical site infection as to that of shaving;

Table 1: Shaving v/s trimming and SSI:

\begin{tabular}{|l|l|l|l|}
\hline Study & Shaving & Trimming & Shaving V/S Trimming SSI Rate \\
\hline Present study & $17 / 181$ & $9 / 184$ & $9.39 \% \mathrm{v} / \mathrm{s} 4.89 \%$ \\
\hline Hamilton HW et al $^{[3]}$ & $6 / 56$ & $3 / 31$ & $10.7 \% \mathrm{v} / \mathrm{s} 9.67 \%$ \\
\hline Cruse P J et al $^{[4]}$ & NA & NA & $2.5 \% \mathrm{v} / \mathrm{s} 1.4 \%$ \\
\hline Balthazar ER et al $^{[5]}$ & $2 / 100$ & $1 / 100$ & $2 \% \mathrm{v} / \mathrm{s} 1 \%$ \\
\hline Alexander JW et al $^{[6]}$ & $31 / 537$ & $14 / 476$ & $5.77 \% \mathrm{v} / \mathrm{s} 2.94 \%$ \\
\hline Ko W et al $^{[7]}$ & $13 / 990$ & $6 / 990$ & $1.31 \% \mathrm{v} / \mathrm{s} 0.60 \%$ \\
\hline Jespen OB et al $^{[8]}$ & NA & NA & $2.5 \% \mathrm{v} / \mathrm{s} 1.7 \%$ \\
\hline Grober ED et al $^{[9]}$ & $2 / 108$ & $2 / 107$ & $1.8 \% \mathrm{v} / \mathrm{s} 1.8 \%$ \\
\hline Gupta MK et al $^{[10]}$ & $113 / 400$ & $60 / 400$ & $28.5 \% \mathrm{v} / \mathrm{s} 15 \%$ \\
\hline
\end{tabular}

Table 2. Time of hair removal and SSI

\begin{tabular}{|c|c|c|c|c|c|c|}
\hline \multirow{2}{*}{ Study } & \multicolumn{3}{|c|}{ Just before (SSI) } & \multicolumn{3}{|c|}{ Day before (SSI) } \\
\hline & Trimming & Shaving & Total $\%$ & Trimming & Shaving & Total \% \\
\hline Present study & $1 / 54$ & $1 / 41$ & $\begin{array}{l}2 / 95 \\
2.10 \%\end{array}$ & $8 / 130$ & $16 / 140$ & $\begin{array}{l}24 / 275 \\
8.88 \%\end{array}$ \\
\hline Alexander JW et al ${ }^{[6]}$ & $7 / 216$ & $26 / 260$ & $\begin{array}{l}33 / 476 \\
6.9 \%\end{array}$ & $18 / 241$ & $23 / 260$ & $\begin{array}{l}41 / 501 \\
8.18 \%\end{array}$ \\
\hline Jespen OB et al $^{[8]}$ & NA & NA & $3.1 \%$ & NA & NA & $7.1 \%$ \\
\hline Seropian $\mathrm{R}$ et al ${ }^{[11]}$ & NA & $4 / 127$ & $3.1 \%$ & NA & $2 / 10$ & $20 \%$ \\
\hline
\end{tabular}

Timing of the hair removal and subsequent time of surgery, this time duration period is important. If the adverse effect of the razor preparation is due to trauma by it and followed by bacterial access and growth, then it is reasonable to expect that this effect will be potentiated if we increase the time duration between hair removal and surgery. ${ }^{[11]}$ Limitations with this study are that, this study had a small sample size. Significant association between method of hair removal and SSI could have been found if the large number of the patients had been taken. Several factors that had shown to affect post operative outcomes on SSI were not included in analysis. In particular, technique of dressing in post operative period, effect of different pre-operative and post-operative antimicrobials, and pre operative scrubbing. Uniformity of these variables was not maintained in study design.

\section{CONCLUSION}

Present study concluded that, patients who had undergone razor shaving have more rate of superficial SSI as compared to patients who had undergone trimming. If hair is removed day before the surgery it increases the rate of SSI as compared to the patients with hair removed just before surgery. So, it is preferable to remove the hair with trimmer just before the surgery. 


\section{ACKNOWLEDGEMENT}

This study has only been possible as a result of the help; we have received from so many people. We are thanking to our ex-head of department Dr. V.P.Hathila, head of department Dr. D.D.Duttaroy, my guide Dr. Samir kacheriwala, my colleagues Dr. Jitendra, Dr. jignesh, Dr. krishna and juniors. We are also thank full to all patients who had given consent to be a part of this study and barbers who co-operate with us very well. In addition, there are many un-named colleagues whom we wish to thank. We would like to thank our immediate families for all their support and in particular our long-suffering spouses. All the time spent on preparation is time when we have been unavailable for them

\section{REFERENCES}

1. CDC. Surgical site infection (SSI) event. http://www.cdc.gov/ nhsn/pdfs/pscmanual19pscssicurrent.pdf. Accessed Feb 20, 2016.

2. Tanner J, Woodings $\mathrm{D}$, Moncaster $\mathrm{K}$ (2006) Preoperative hair removal to reduce surgical site infection. Cochrane Database Syst Rev 19: CD004122.

3. Hamilton HW, Hamilton KR, Lone FJ: Preoperative hair removal. Can J Surg 1977; 20: 269-275.

4. Cruse PJ, Foord R. The Epidemiology of wound infection: A 10-year prospective study of 62,939 wounds. Surg Clin North Am. 1980; 60(1): 27-40.

5. Balthazar ER, Colt JD, Nichols RL. Preoperative hair removal: a random prospective study of shaving versus clipping. South Med J. 1982; 75(7): 799801.

6. Alexander JW, Fischer JE, Boyajian M, Palm quist J, Morris MJ. The influence of hair-removal methods on wound infections. Arch Surg. 1983;118(3):347352.
7. Ko W, Lazenby WD, Zelano JA, Isom OW, Krieger KH. Effects of shaving methods and intra operative irrigation on suppurative mediastinitis after bypass operations. Ann Thorac Surg. 1992; 53(2):301-305.

8. Jepsen OB, Bruttomesso KA. The effectiveness of preoperative skin preparations: An integrative review of the literature. AORN Journal. 1993;58:477484.

9. Grober ED, Domes T, Fanipour M, and Copp JE. Preoperative hair removal on the male genitalia: Clippers vs. razors. J Sex Med 2013;10:589-594.

10. Gupta MK, Gupta V, Kant K : A prospective study of evaluation of different methods of pre-operative hair removal and their relationship to postoperative wound infection JMSCR Volume 2,Issue (10) ;2669-2675: October 2014

11. Seropian R, Reynolds BM. Wound infections after preoperative depilatory versus razor preparation. Am J Surg. 1971; 121 (3) 251- 254.

\section{LIST OF ABBREVEATIONS}

$\begin{array}{ll}\text { CDC }= & \text { Centre of Disease Control } \\ \text { NA }= & \text { Not available } \\ \text { SSGH }= & \text { Sir Sayajirao General Hospital } \\ \text { SSI }= & \text { Surgical Site Infection }\end{array}$

